\title{
Epistemic Cartography: Evaluating Net-Map as a Frontline Tool for Navigating Informal Knowledge Networks
}

\author{
Luke Metelerkamp, Rhodes University, South Africa, and Eva Schiffer, Dexis Consulting, Denmark
}

\begin{abstract}
Sustainability transitions are dependent on the development and diffusion of transformative skills and competencies. However, the prevailing notion that learning for sustainability transitions will be led by universities, technical colleges and other similar institutions is practically not feasible in much of the global south. Net-Map is a social network analysis tool that uses interviews and mapping to help people understand, visualise, discuss, and improve situations in which many different actors influence outcomes (Schiffer \& Hauck, 2010). In response to the pressing need for new approaches to the development and diffusion of sustainability skills, this paper evaluates Net-Map's suitability as a methodological tool for educators, knowledge brokers and students seeking to enhance the navigability of the often complex and uncharted occupational pathways they encounter. To do this, the research applied Net-Map to an emerging sustainability niche within the food system in order to map the learning pathways of successful sustainability pioneers. We found that NetMap was helpful in identifying diffuse informal knowledge networks and teaching resources. Being free, quick to learn and easy to use, Net-Map is a potentially low-cost method for circumventing traditionally costly approaches to curriculum development and accreditation - assisting community-based actors to make sense of the informal knowledge and competency networks that support emerging career fields. In emerging career fields such as organic farming, where pioneer knowledge is fragmented, poorly documented and often disregarded by mainstream-science, NetMap could be useful in the preparatory phase of curriculum planning and design, providing training designers, course conveners and facilitators with contextually informed insights.
\end{abstract}

Keywords: Net-Map, knowledge networks, agricultural curriculum, sustainability skills, skills ecosystem, transitions

\section{Introduction}

Sustainability transitions are dependent on the development and diffusion of new competencies. A transition to a global food system based on principles of social and environmental justice, for example, will rely on vast numbers of young people learning how to farm, trade and self-organise in new ways (Klerkx, Hall \& Leeuwis, 2009; Kabasa, Kirsten \& Minde, 2015; 
Yeboah, 2018). The prevailing notion that learning for these kinds of transitions will be led by universities, technical colleges and other similar institutions is unlikely to hold true for much of the global south. Of the 800 million youth projected to enter the job market in Africa over the next 30 years (Losch, 2016), only 10\% will have a tertiary qualification (Minde et al., 2015; Darvas et al., 2017). While we need to question the type and quality of skills this $10 \%$ will acquire in tertiary training, the far bigger question is: 'What about the other $90 \%$ ?' If this $90 \%$ is not formally trained, how do we consider engaging this overwhelming majority in the imagining and construction of a better future?

This simple question highlights the need for increased research into ambitious alternatives to the existing capacity building platforms. From a sustainability perspective, recognising the limitations in formal training highlights the need to begin thinking about how to increase the dissemination and diffusion of new knowledge and competencies from within emerging sustainability niches - particularly in the global south, but also in the north. Theorists from across the fields of sustainability transitions, pedagogy and complexity, respond by arguing for the need to take a networked view on the development and diffusion of competency at an individual and societal level (Carlsson \& Stankiewicz, 1991; Reed et al., 2010; Kilelu et al., 2011; Goodyear \& Carvalho, 2013; Lotz-Sisitka et al., 2015; Kelly, Bennet \& Starasts, 2017; Wals et al., 2017). Concurrently, there is an increase in voices calling for more place-based approaches to learning which embrace the notion of learning through context-sensitive practice (Smith, 2002; Sobel, 2004; Gruenewald \& Smith, 2014; Vallabh et al., 2016; Shannon \& Galle, 2017). These place-based approaches, which use students' local community and environment as a starting point for learning, encourage academic achievement while developing a heightened commitment to serving as active, contributing citizens (Sobel, 2004). It can also be argued that foregrounding local knowledges and centring the forms of learning that take place through localised lived experience are opportunities for deconstructing hierarchical epistemic traditions (O’Donoghue, et. al. 2019, Mendoza-Zuany \& Shava, 2019).

In response to the need for new approaches to education which are both inclusive and transformative, we see a role for increased attention to new methodological tools for curriculum development - methods capable of translating place-based pedagogies into practice at a grassroots level where institutional capacity is weak and educators themselves lack the very skills they strive to pass on to their students.

\section{Considering where transformative knowledge resides}

In thinking about systemic transitions, such as in the agricultural sector, Carlsson and Stankiewicz (1991) highlighted the need to consider the centrality of competency flows and the institutions that enable these:

Technological systems are defined in terms of knowledge or competence flows rather than flows of ordinary goods and services. They consist of dynamic knowledge and competence networks... [N]etworks of agents interacting in a specific technology area under a particular institutional infrastructure to generate, diffuse and utilize technology. (p.111) 
Similarly, in their research relating specifically to food system transformation, Goodman, DePuis and Goodman (2012) highlighted that network processes of knowledge transmission are the catalyst for expansion by horizontal replication. In other words, horizontal (or peerto-peer) knowledge networks are a means through which pioneer projects can multiply their effect.

Viewing systemic transitions from this perspective "highlights more explicitly the importance not only of understanding the creation of transformative technology, but also its diffusion and utilization" (Geels, 2004, p. 898. Own emphasis). This emphasis on the networked nature of competence is shared by a range of pedagogical theorists (Hakkarainen et al., 2004; Lorentzen, 2008; Moore \& Westley, 2011; Hakkarainen et al. 2013; Torre et al., 2016).

Taking this further, theory from the field of Transitions Management suggests that transitions within complex systems require a mix of three distinct types of knowledge: systems, target and transformative knowledge (Pohl \& Hadorn, 2007; Rauschmayer, Bauler \& Schäpke, 2015). Formal research institutions tend to do better at developing systems and target knowledge than transformative knowledge. Sustainability scholars and educators tend to have a better idea of current issues and where we would like to be than of how to get there uncertainty is inherent in complex challenges and transformations. In almost all cases, the path is not clear yet, and needs to be created as the system's actors experiment with new behaviours. The generation of new competencies for transformation (transformative knowledge) is often a bottom-up process, which occurs on the fringes of the established system. This suggests that in our attempts to identify and access transformative knowledge for teaching purposes, we need to be looking beyond the formal channels of institutionalised innovation - particularly in economies where public research institutions are under-resourced.

\section{Research objective}

In light of the need for more inclusive approaches to the development and diffusion of sustainability skills, this paper evaluates the potential of Net-Map, a social network analysis tool that uses interviews and mapping to help people understand and improve situations in which many different actors influence outcomes (Wikipedia, 2020), as a supportive tool for transgressing the boundaries of formal, hierarchical education.

In addition, this paper sought to support a growing body of work around networked approaches to learning and competency. It offers a methodological starting point for educators, knowledge brokers and students seeking to enhance the navigability of the often complex and uncharted occupational pathways they encounter.

\section{Design and methodology}

\section{Case study}

Southern Africa faces a range of social, economic, and environmental challenges. Of particular relevance is the food system, which is associated with a wide range of environmental problems as well as social inequalities and injustices (Patel, 2012; IPCC, 2014; FAO, 2016). In some parts 
of the region, the food economy accounts for as much as $80 \%$ of livelihoods. The majority of these livelihoods are in the informal economy (Tschirley et al., 2015).

For these reasons, testing the applicability of Net-Map on an occupational cluster centring around more sustainable food production seemed useful. The organic agricultural sector in South Africa is in its infancy. It is also very loosely organised and lacks any official regulation or formal qualifications (Kelly \& Metelerkamp, 2015). Thus it was an ideal case study for testing Net-Map.

\section{Overview of Net-Map process}

Net-Map was originally developed to better understand multi-stakeholder systems by gathering in-depth information about resource networks, goals of actors, and their power to influence system outcomes (Schiffer \& Hauck, 2010). Net-Map merges two existing methods, namely social network analysis and power-mapping. As a research method, it is well-suited to the collection of qualitative and quantitative information in a structured and comparable way (Schiffer \& Waale, 2008).

Net-Map enables participants within a particular system to surface and explain the diverse and often obscure spectrum of actors who exert influence over the outcome of a particular objective or process within that system. For this study, Net-Map was applied to an emerging sustainability niche within the food system. The resultant network maps indicated who the relevant actors were, the kinds of information they contributed to their community, the ways in which they were connected to one another and, finally, the power they were considered to wield within the system (Schiffer \& Waale, 2008).

Generally, the Net-Map process consists of five steps - these are described below in the light of their application to the current research process.

\section{Step 1. Prompting question}

A clear prompting question is required to demarcate the boundaries of the Net-Mapping process for participants.

The prompting question posed to interviewees in this case study was:

Who are the actors that influence the success of an organic farmer in South Africa and how [/to whom] are they accountable?

This prompting question enabled the research to focus on the full spectrum of actors influencing the success of farmers rather than a direct question about who their knowledge resources were. This was done for two reasons: firstly, we wanted to construct a holistic picture of the full range of actors at play in their lives because, from a capacity-building perspective, these actors benefit from training targeted towards this occupational pathway. Secondly, approaching the topic of learning too directly could bias responses and result in the exclusion of valuable insights due to differences in respondents' understandings about what constituted a useful knowledge resource. 


\section{Step 2. Listing actors}

Working together on a large sheet of paper, the interviewer assisted with listing all the actors whom the interviewee felt influenced success within the particular occupational pathway for the given region, in this case an organic farmer in South Africa. At the discretion of the respondent, each actor was classified into one of five categories: Farmer, Community, Civil Society, State and Private Sector.

Importantly, respondents were not unified in their classifications of actors. For example, Farmer 5 listed "internet \& YouTube" as a farmer-based actor because they were using it to access others farmers' knowledge. Farmer 3 listed this as a community-based actor because of the general spirit in which it was created and shared. In most cases these differences were not problematic and could be reconciled during data analysis.

\section{Step 3. Network mapping}

The interviewer then guided the interviewee to establish the nature of the linkages between each of the identified actors based on a set of five pre-determined types: information, finances, resources, advocacy and authority. Each of the five types was listed using a different colour (see Figure 1). Respondents denoted the direction of the relationship as to/from/bidirectional.

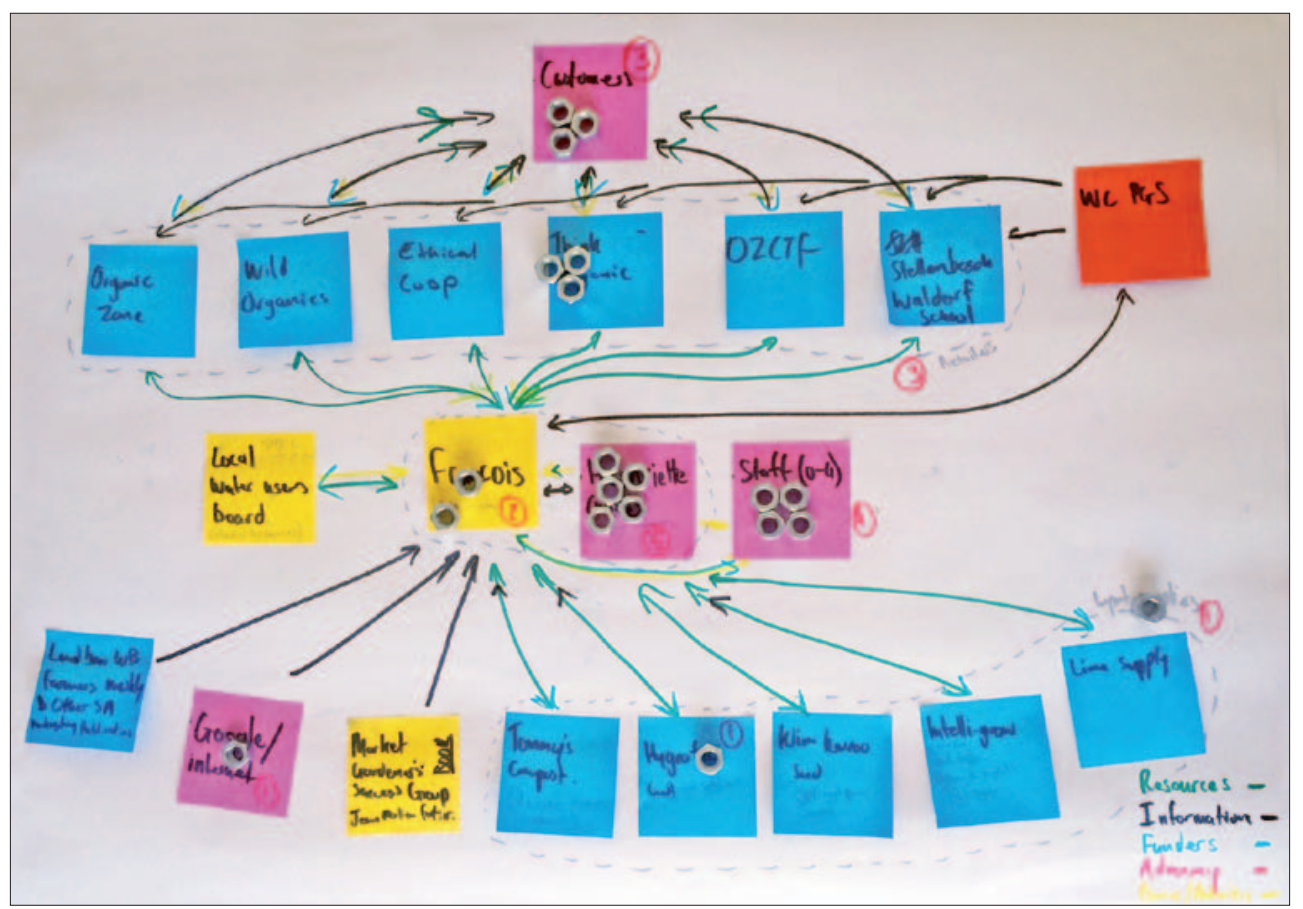

Figure 1 Example of a completed farmer Net-Map 


\section{Step 4. Allocating influence}

Once the actors and their links with other actors were established, the influence of these actors was determined using checkers pieces to construct influence towers. This allowed the abstract concept of power and influence to be tangibly represented in a three-dimensional form. A limited number of checkers pieces were provided so interviewees had to consider carefully who the most influential actors were.

\section{Step 5. Reflection and discussion}

Net-Maps serve as useful boundary objects for anchoring complex discussions (Hauck et al., 2015; Stein \& Barron, 2017) and the process naturally tended to evoke substantial reflection and explanatory discussion from the participants. Allowing participants to embark on tangents and enter into storytelling mode as they were developing their networks, appeared to increase the amount of actors and connections they listed. At the end of the process, as time allowed, participants would be invited to step back from their network maps, reflect on what they had laid out and make any amendments they felt were necessary.

\section{Sample}

The Net-Map method was applied by individually interviewing a sample of organic farmers and related sector organisations.

A snowballing sampling process was used to develop a shortlist of 50 organic farmers and supporting organisations in the Western Cape Province of South Africa. Each of these 50 actors were then rated against a common set of criteria to produce a shortlist of five farmers, each representing a different scale of operation (see Tables 1 and 2).

Table 1 List of farmer respondents

\begin{tabular}{|l|c|c|}
\hline Farm type & Years in operation & Farm size \\
\hline Urban community school garden & 1 & 0.1 ha \\
\hline Peri-urban micro vegetable farm & 2 & 0.5 ha \\
\hline Rural vegetable farm & 10 & $1.5 \mathrm{ha}$ \\
\hline Peri-urban vegetable farm & 14 & $10 \mathrm{ha}$ \\
\hline Urban vegetable farm & 11 & $24 \mathrm{ha}$ \\
\hline
\end{tabular}


Table 2 List of sector organisation respondents

\begin{tabular}{|l|c|}
\hline Organisation type & $\begin{array}{c}\text { Respondent years' } \\
\text { experience }\end{array}$ \\
\hline Retail cooperative & 7 \\
\hline Sector activist & 7 \\
\hline Sector representational body and trainer & 44 \\
\hline Local fresh produce market & 25 \\
\hline Rural development and organic participatory guarantee systems & 10 \\
\hline Provincial Department of Agriculture & 9 \\
\hline Farmer advocacy and training & 40 \\
\hline
\end{tabular}

Twelve Net-Maps were subsequently presented to an expert panel of 25 regional and international sector representatives and farmers. Through facilitated small-group engagement with the Net-Maps, this panel reflected on the Net-Maps and their inputs informed an overarching analysis.

\section{Results}

The maps varied greatly in nature. In total, the respondents listed 380 actors and 880 relationships. On average, farmers listed 17 actors in their Net-Maps, while sector organisations listed 43. The level of connectivity and complexity depicted in individual Net-Maps also varied greatly. On the whole, farmers tended to list individuals and identify the factors influencing their success in simpler, more direct terms than sector organisations. Differences such as this highlighted that the process is not so much about mapping reality, but rather mapping network perceptions which provide the basis for behaviours and decision-making.

Prevalence and influence were also considered in the analysis. Prevalence refers to the frequency with which an actor or category of actors appeared. Influence refers to the weighting interviewees allocated a particular actor or grouping of actors.

\section{General actors and influencers}

The most influential actors in the eyes of farmers were members of their community (36\%) and the private sector (24\%). The least influential were civil society (16\%), state actors (11\%) and other farmers (11\%). The most commonly listed were private sector (42\%), community (19\%) and other farmers (19\%). The state and civil society were listed least frequently (12\% and $9 \%$ respectively).

The most influential actors in the eyes of sector organisations were civil society (27\%) and the private sector (23\%). These were also the most commonly listed (28\% and $24 \%$ respectively). The least influential were other farmers (12\%) and community actors (11\%). Community and other farmers were also listed least frequently ( $13 \%$ and $10 \%$ respectively). 


\section{Focus on learning networks}

The Net-Maps indicate to whom farmers turn for knowledge, as well as those to whom they do not. They provide an initial indication as to whether there are particular concentrations of knowledge and experience in the system and which specific individuals or institutions appear to be making substantial contributions to the learning taking place within the niche. Of the 380 listed actors, approximately 30\% (124) were identified by interviewees as having knowledge or information flowing to organic farmers. Figures 2 and 3 provide a distillation of the farmer and sector organisation Net-Map data filtered for information exchange and coloured by classification. Table 3 provides the related numeric breakdown.

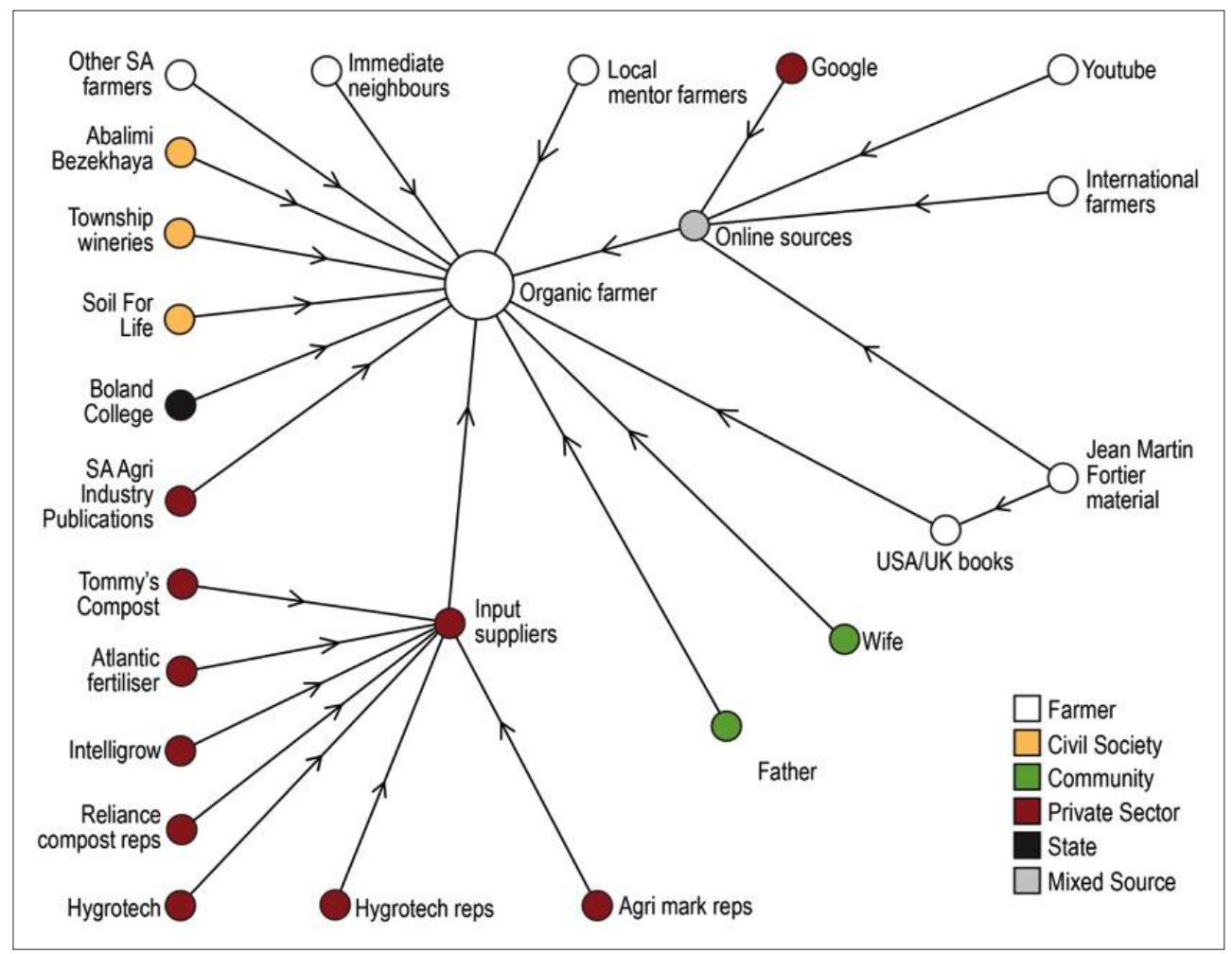

Figure 2 Combined network map of all actors identified by farmers as sources of information that influenced their success 


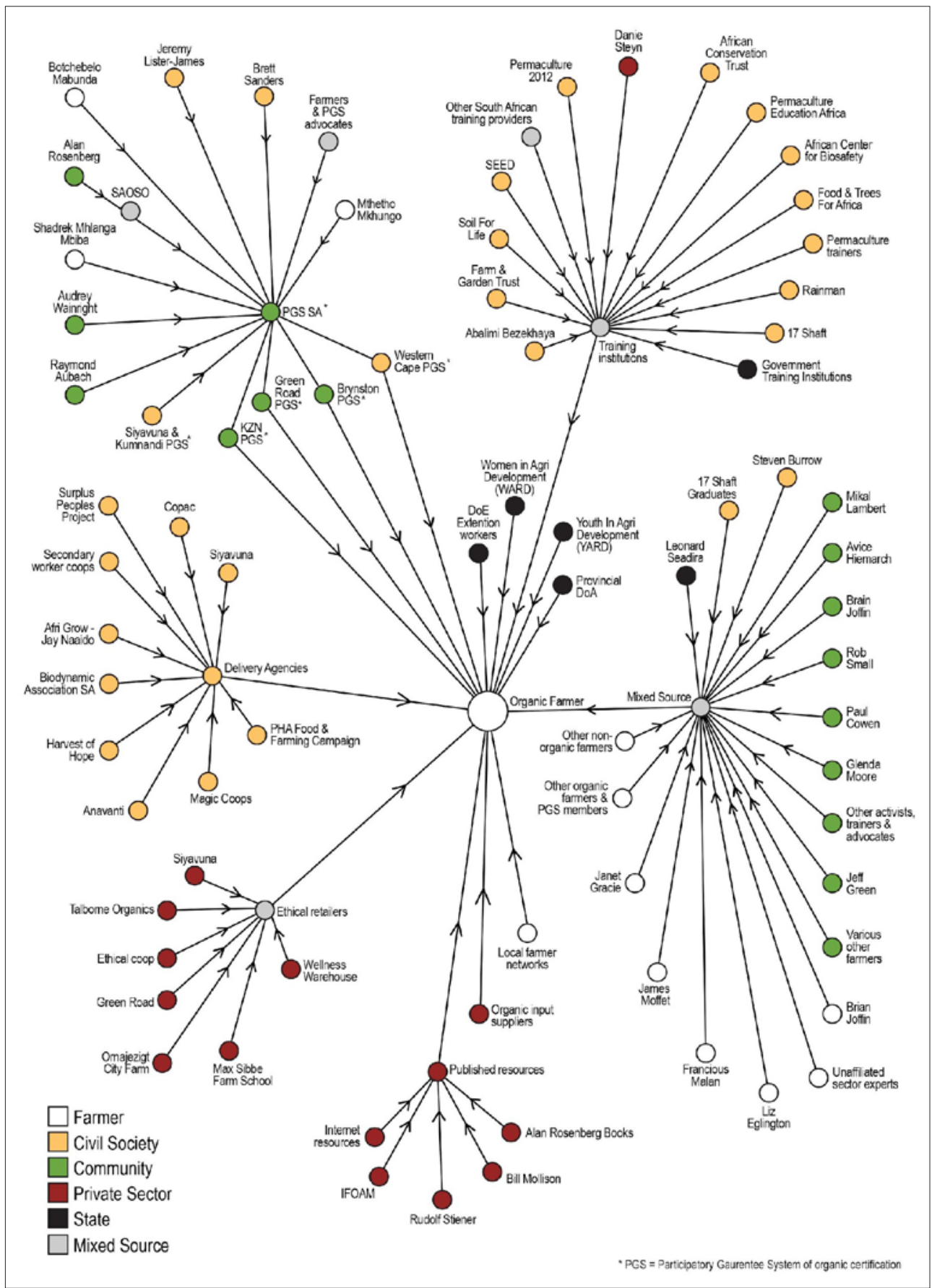

Figure 3 Combined network map of actors identified by sector organisations as influential information partners to organic farmers 
Table 3 Information sources as listed by farmers and sector organisations

\begin{tabular}{|c|c|c|c|}
\hline $\begin{array}{l}\text { Farmer } \\
\text { knowledge } \\
\text { resources }\end{array}$ & $\begin{array}{l}\text { Percentage of } \\
\text { total actors }\end{array}$ & Number & Example \\
\hline Private Sector & $42 \%$ & 10 & $\begin{array}{l}\text { Hygrotech }{ }^{1} \text { sales representatives, Reliance } \\
\text { Compost sales representatives }\end{array}$ \\
\hline Farmer & $29 \%$ & 7 & $\begin{array}{l}\text { Immediate neighbours, other SA farmers, } \\
\text { Market Gardeners Success Group, Google, } \\
\text { YouTube }^{2}\end{array}$ \\
\hline Civil Society & $13 \%$ & 3 & Abalimi, Soil for Life \\
\hline Community & $13 \%$ & 3 & Google, YouTube, wife \\
\hline State & $4 \%$ & 1 & Boland College \\
\hline $\begin{array}{l}\text { Sector } \\
\text { Organisation } \\
\text { knowledge } \\
\text { resources }\end{array}$ & $\begin{array}{l}\text { Percentage of } \\
\text { total actors }\end{array}$ & Number & Example \\
\hline Civil Society & $44 \%$ & 43 & $\begin{array}{l}\text { Western Cape Participatory Guarantee } \\
\text { System, Abalimi Bezikhaya }\end{array}$ \\
\hline Private Sector & $18 \%$ & 18 & Ethical Co-op, Internet, Input Suppliers \\
\hline Community & $17 \%$ & 17 & Sector activists \\
\hline Farmer & $13 \%$ & 13 & Local farmer networks \\
\hline State & $7 \%$ & 7 & $\begin{array}{l}\text { Department of Agriculture, individual } \\
\text { departmental advocates }\end{array}$ \\
\hline
\end{tabular}

\section{Discussion}

This research suggests Net-Map could be a supportive tool within sustainability transitions and the method could serve as a useful tool to support curriculum designers, facilitators and students. The discussion that follows is presented in two sections: strengths of the method, followed by its weaknesses. Based on this, a revised version of the standard Net-Map method is provided aimed specifically at use in the educational context.

\section{Strengths of the method}

Net-Map proved well suited to supporting learning within niche environments, although it was not originally intended for use in an educational context. The strengths of the methods are discussed briefly below, after which certain limitations are listed. 


\section{Surfacing system structure and relationships}

Firstly, Net-Map proved to be a simple and relatively rapid means to engage with the knowledge embedded within a particular context. Using Net-Map can assist a training organisation to surface critical relationships relating to the particular competency or career trajectory they are seeking to support.

Net-Map not only provided a overview of how a wider community of actors influence success within a given discipline, it also helps to protect against the potential blind-spots within existing curricula. In our case study, for example, sector organisations appeared to be overlooking the important role of supportive partnerships at home, online learning and the specific role which private sector actors played in the success of pioneering farmers.

\section{Identifying keystone knowledge brokers}

Having established a basic model of the relationships that were important to the success of organic farmers, the Net-Map process further provided a simple means by which to identify regional actors who were particularly central to what Carlsson and Stankiewicz (1991) referred to as the 'diffusion and flow' of knowledge across the network. These keystone knowledge brokers appear to play a 'pollinator role', joining the dots between common problems and emerging solutions. By their nature they tend to be connected to far more nodes in the system than the average actor, and they tend to feature consistently in Net-Maps showing different kinds of actors. Ethical Co-op, for example, appeared as a richly connected actor in seven of the 12 Net-Maps suggesting that it held a central role within the network economy. From an educational perspective, understanding who these actors are is important as they may serve as enabling allies providing advice and access to network resources. Furthermore, O'Donoghue et al (2019), suggest that actors such as these may also serve as vital links in the intergenerational transmission of local knowledge, cultures and values.

\section{Identifying subject specialists}

Following this, curriculum designers, facilitators and students can use Net-Map to assist in identifying content specialists in contexts where knowledge is both fragmented and poorly archived. Using the different colour lines to indicate different forms of connection between actors, helps educators and students understand which kinds of actors hold knowledge on specific aspects of the system. Additionally, the influence weighting attributed to each actor in the individual Net-Maps is an indication of the potential importance of the knowledge particular actors have to offer.

The Net-Maps generated in the process provide a quick and easy reference point for facilitators and course coordinators seeking to bring in specialist guest presenters, plan field trips or organise internships. Table 4 provides an example of how data from the Net-Maps can be distilled into a local competency catalogue. Central to the power of these kinds of competency catalogues is that they are peer reviewed by practitioners through the Net-Map process (we elaborate on this in the following section). 
Table 4 Abbreviated example of local competency catalogue

\begin{tabular}{|l|l|}
\hline Key competencies & Competency specialists \\
\hline Organic vegetable production & $\begin{array}{l}\text { Francios Malan, Jacques Olivier, Skye Felman, } \\
\text { Market Gardeners Success Group }\end{array}$ \\
\hline Seed and seedling production & Hygrotec and Klein Karoo Seed \\
\hline Compost production & Tommy's Compost, Reliance Compost \\
\hline Record keeping and accounting & Henriette Malan \\
\hline Alternative retail systems & $\begin{array}{l}\text { Ethical Coop/Anique van de Vlugt, Wild } \\
\text { Organics, Audrey Wainright, Market Gardeners } \\
\text { Success Group }\end{array}$ \\
\hline Philosophy of agroecology & Alan Rosenberg, Raymond Auerbach \\
\hline Communal farming and urban food gardens & Soil For Life, Rob Small \\
\hline
\end{tabular}

\section{Verifying practitioner knowledge in the absence of formal qualifications}

The case study suggested that often those most qualified to teach within transitional spaces are practitioners and activists who possess a proven ability to function within the system but have no formal qualification relating to their expertise. This raises the need for ways of validating expertise and establishing who subject specialists are.

When attempting to support competency development within niche spaces, which by their nature attract radical thinkers, the challenges faced by students and facilitators in discerning fact from fiction should not be underestimated.

To overcome these challenges, the Net-Map process provides a form of grass-roots peer review for knowledge sources within a given network. As they seek to overcome their day-today challenges, niche actors are continually trialling solutions. Based on this, we assert that the level of influence attributed to a particular knowledge source and the number of niche actors who make reference to a given information source, can be used as a means of verifying the degree to which a particular knowledge source (or type of knowledge source) can be depended on in a given context.

\section{A supportive tool in the absence of formal articulation frameworks}

While the validation of knowledge is important, this also needs to be pitched at the relevant level. The kind of information sources that yield value for an actor with 10 years of experience, may differ significantly from the needs of a young entrant taking their first tentative steps into a new career. While it was not a direct aim of our study to test the application of Net-Map for this purpose, a reflection on our process suggests potential in this regard.

Our study covered a broad spectrum of farmers ranging from those working in a fledgling 0.1 ha community garden to a well-established 24 ha commercial operation (see Table 1 ). We noted that as the nature of each operation changed, so too did the kind of knowledge and 
supporting knowledge resources. While more data points for each scale of farming would be necessary before conclusions could be drawn, an initial review of the Net-Maps of the five distinct farm types displayed substantial differences. For example, farmers in the earlier stages of their careers tended to turn more towards civil society organisations and more established farmers. In turn, these more established farmers appeared to have outgrown the available local resources and resorted increasingly to a smaller handful of international knowledge resources.

\section{Assisting in understanding the learning resources required by students}

Once a list of key knowledge resources has been defined, an assessment can be made to determine the kinds of learning resources required in order to access these knowledge resources.

Understanding the nature of knowledge resources operating within a given niche or career field allows facilitators to begin asking the relevant questions: if key online resources are available for free, then do students have access to smartphones or computers to access these? Do they need mobile phone data to be able to work from home? And so forth. For students for whom English is not their home language, translation of material may be an additional consideration.

Building on this, Table 5 provides examples of case study specific insights for localised agroecological food systems. The research identified six particular groups of influential knowledge partnerships that could be of value to educators seeking to support aspirant farmers.

Table 5 Examples of case study specific learning insights from Net-Map process

\begin{tabular}{|c|c|}
\hline Knowledge actor & Notes for educators \\
\hline $\begin{array}{l}\text { Online knowledge } \\
\text { communities and }\end{array}$ & $\begin{array}{l}\text { A wide range of free and high value learning material exists online. } \\
\text { However, for those without extensive practical knowledge in the field, } \\
\text { sifting through the plethora of international sources to determine the } \\
\text { true utility of information and its local applicability can be challenging. } \\
\text { Probing successful farmers for the online resources they trust and use most } \\
\text { frequently provides a reliable screening and validation approach. }\end{array}$ \\
\hline & $\begin{array}{l}\text { Once these online resources have been curated, sharing this information } \\
\text { with other, less experienced or less online-savvy farmers could highly } \\
\text { increase their effectiveness and efficiency of accessing useful information } \\
\text { online. }\end{array}$ \\
\hline $\begin{array}{l}\text { Alternative } \\
\text { retail outlets } \\
\text { and consumer } \\
\text { cooperatives }\end{array}$ & $\begin{array}{l}\text { These are keystone actors in the system that tend to be very well networked } \\
\text { potentially making them critical knowledge brokers. Because they engage } \\
\text { with a large number of farmers, they tend to have the most accurate picture } \\
\text { regarding the most successful farmers and where they are based. They are } \\
\text { also well positioned to provide information on other markers of agricultural } \\
\text { success. }\end{array}$ \\
\hline
\end{tabular}




\begin{tabular}{|c|c|}
\hline Knowledge actor & Notes for educators \\
\hline $\begin{array}{l}\text { Private sector } \\
\text { input suppliers }\end{array}$ & $\begin{array}{l}\text { Expecting farmers to be achieving the idealistic goal of total farm sufficiency } \\
\text { in terms of generating farm inputs such as seedlings and compost is } \\
\text { setting them up for failure. Relationships with good compost and seedling } \\
\text { suppliers emerged as particularly important to success not only because of } \\
\text { the critical materials they supplied, but also because they unlock access to } \\
\text { important specialist information. Private sector input suppliers like these } \\
\text { play an important role in the niche which should not be underestimated. } \\
\text { As with retailers, input suppliers share a vested interest in farmer success. } \\
\text { Unlike agricultural extension agents, farmers beyond the subsistence level } \\
\text { tend to see input providers and retailers on a regular basis, so both can be } \\
\text { effective connectors to a large base of farmers. }\end{array}$ \\
\hline $\begin{array}{l}\text { Home } \\
\text { relationships }\end{array}$ & $\begin{array}{l}\text { Successful farmers did not make it alone; most appeared to have succeeded } \\
\text { as a close-knit husband/wife team. This suggests that farmers should not } \\
\text { be trained in isolation. Thought should be given to jointly capacitating } \\
\text { husbands/wives/families in other aspects of farm business. This appeared } \\
\text { to be a major blind spot among supporting organisations. }\end{array}$ \\
\hline $\begin{array}{l}\text { Other successful } \\
\text { farmers in local } \\
\text { context }\end{array}$ & $\begin{array}{l}\text { In the organic context, given how few farmers exist, care needs to be } \\
\text { taken not to overwhelm them with requests for guidance. Working to } \\
\text { document and digitise this pioneer knowledge may be one way of greatly } \\
\text { expanding access to valuable knowledge resources without over burdening } \\
\text { practitioners with teaching requests. } \\
\text { Involving farmers' spouses in training processes may also assist in } \\
\text { expanding teaching capacity. }\end{array}$ \\
\hline $\begin{array}{l}\text { Civil society } \\
\text { organisations }\end{array}$ & $\begin{array}{l}\text { Play an important role in the learning landscape of some niche actors - } \\
\text { particularly emerging farmers. This is probably especially true in contexts of } \\
\text { great inequality. }\end{array}$ \\
\hline
\end{tabular}

\section{Limitations of Net-Map}

Net-Map was not originally intended for use in an educational context. Despite this, it proved well suited to supporting learning within niche environments. In order to refine its efficacy in these spaces we reflect on a number of potential limitations that were observed.

\section{Blind spots and social bias}

Net-Map was good at identifying where exchanges of information were taking place. However, in the case where no connection was present, it was not always clear if this was because the actors were not of value or if they were not connected to the prevailing social network being sampled. This has the potential to create blind spots in the knowledge landscape where actors who are not richly connected, are assumed not to have valuable knowledge. 


\section{Overlaps between competence and incompetence}

If network connectivity, frequency and influence are to be used as a frontline proxy for knowledge validation in the absence of scientific or curriculum review processes, care needs to be taken in determining which specific competencies the network is ascribing to a specific actor and which they are not. Without careful documentation of this qualitative, actor-specific information, there is a risk that competence in a specific area results in false assumptions of competence in other fields. The fact that an actor has become a knowledge resource through their mastery of one aspect of a system does not mean their knowledge around other aspects is deemed credible by the network.

We found that adding simple notes to the connection arrows enabled us to ensure this information was reflected in the final maps.

\section{Reliant on social capital}

As the strength of the process rests on being able to get direct information from the most successful actors within a given system, the absence of sufficient social capital required to access these actors could make the Net-Map process difficult and time-consuming to execute effectively.

\section{Customised Net-Map approach}

In weighing up the strengths and limitations of Net-Map as a support tool in educational contexts, a noteworthy attribute of the method is the ease with which it can be adapted on the ground, to fit the needs of a specific context. Thus, while Net-Map in its current form yielded some useful insights, customisation of the method that can further improve its utility to educators is relatively simple. As alluded to earlier, gathering education-specific baseline information during the mapping process could make a big difference in the use of the NetMaps to support learning processes.

An indication of some important educational characteristics of the listed actors could include:

- Availability and/or interest of an actor to be involved in teaching;

- Level of teaching experience;

- Nature of the potential teaching resource (digital/institution/individual); and

- Specific area of competency.

The main challenge in customisation is balancing the desire to add new layers of data collection with the need to retain the simplicity that makes the method so effective. Therefore, in thinking about process customisation, thought needs to be given to layers of data collection that can be discarded, as much as to those which can be added.

Using the insights listed above, Metelerkamp and Biggs (2020) have developed a simple practitioners' tool kit for using Net-Map in educational settings. 


\section{Joining the dots in practice}

The effectiveness of niche networks depends on the collective capacity to facilitate exchanges of information and resources. In the terminology of network analysis, this capacity is known as the network's 'navigability' (Buchanan, 2002; Spielman et al., 2008). For those working in emerging knowledge environments, Net-Map, quite literally, provides a means to map out uncharted actor networks so that they can be effectively navigated.

In the context of emerging career fields, where pioneer knowledge is fragmented and poorly documented, Net-Map could prove useful as an entry point during the preparatory phase in curriculum planning and design - particularly in assisting training designers, course conveners and facilitators to move beyond flawed assumptions and uncertainty in order to provide contextually informed insights into:

1. What should be taught?

2. Who/what are the most suitable actors and resources are for teaching this?

3. What kinds of networks of relationship matter most for the local working context students are entering?

4. Pathways for supporting students to cultivate these relational networks.

In doing so, Net-Map enhances the navigability of locally grounded networks of practice by providing answers to some of these 'who', 'how' and 'where' questions.

Furthermore, we believe there to be a secondary opportunity for the use of Net-Map by students, empowering them to focus on existing local knowledge within their own communities.

For students Net-Map is a practical tool for answering questions like:

1. Are there existing informal networks within my context that can support my journey?

2. What kinds of things do I need to be learning about in order to succeed in my context?

3. Who/what are the best available resources I can draw on for this learning that have worked for others like me?

4. When faced with a particular kind of challenge, who can I turn to?

\section{Conclusion}

In light of the need for more inclusive approaches to the development and diffusion of sustainability skills, this paper has evaluated Net-Map's utility as a supportive tool for transgressing the boundaries of formal, hierarchical education.

In the case study, Net-Map was shown to be capable of surfacing informal learning networks and the knowledge resources that influenced the successful establishment of new kinds of livelihoods. It also demonstrated that it could assist in validating these informal knowledge resources through a simple form of practitioner peer-review.

These attributes make Net-Map a potentially low-cost method for circumventing traditionally costly approaches to curriculum development and accreditation. In doing so, it could assist community-based actors to make sense of the confusion surrounding emerging 
career fields. The method's ability to connect learners to communities of practice also implies alignment with the kinds of place-based pedagogies advocated by educational theorists engaging with questions of socio-ecological sustainability (Sobel, 2004; Parr \& Van Horn, 2006; Spielman et al., 2008; Wals et al., 2017).

Importantly, the research did not go on to test the application of the method empirically with students. Nor did it undertake a direct comparison with other approaches. As such, we suggest cautious experimentation with this tool in educational contexts in parallel with existing approaches. Empirical testing of the revised method is needed to begin developing a more comprehensive understanding of the potential efficacy of Net-Map in an educational setting.

\section{Endnotes}

1. Hygrotech is a local supplier of seedlings, irrigation systems and agricultural inputs. The company approach is sensitive to ecologically friendly agriculture.

2. While Google and YouTube were not knowledge actors in their own right, they featured repeatedly as the primary portals for the online problem solving.

\section{Notes on the contributors and their contributions}

\section{Lead author}

Metelerkamp, Luke

Luke Metelerkamp is a post-doctoral researcher at the Environmental Learning Research Centre at Rhodes University. His work focusses on the intersections between informality, skills development and food system transitions.

\section{Co-author}

\section{Schiffer, Eva}

Eva Schiffer is the team lead for Human Capital Learning and Training at Planet Partnerships. Her work with Net-Map has helped researchers, change managers, project teams and individuals to identify bottlenecks and think more strategically about stakeholder engagement.

\section{Percentage contribution}

\begin{tabular}{|l|l|c|}
\hline Areas of contribution & Author & $\begin{array}{c}\text { Percentage } \\
\text { contribution }\end{array}$ \\
\hline $\begin{array}{l}\text { Conception or design of the paper, theory or } \\
\text { key argument }\end{array}$ & Metelerkamp & $100 \%$ \\
\cline { 2 - 3 } & Schiffer & $0 \%$ \\
\hline
\end{tabular}




\begin{tabular}{|l|l|r|}
\hline \multirow{2}{*}{ Areas of contribution } & Author & $\begin{array}{r}\text { Percentage } \\
\text { contribution }\end{array}$ \\
\hline \multirow{2}{*}{ Data collection } & Metelerkamp & $100 \%$ \\
\cline { 2 - 3 } & Schiffer & $0 \%$ \\
\hline \multirow{2}{*}{ Analysis and interpretation } & Metelerkamp & $80 \%$ \\
\cline { 2 - 3 } & Schiffer & $20 \%$ \\
\hline \multirow{2}{*}{ Drafting the paper } & Metelerkamp & $100 \%$ \\
\cline { 2 - 3 } & Schiffer & $60 \%$ \\
\hline \multirow{2}{*}{ Critical review of the paper } & Metelerkamp & $40 \%$ \\
\cline { 2 - 3 } & Schiffer & \\
\hline
\end{tabular}

\section{References}

Buchanan M. (2002). Small Worlds and the Groundbreaking Theory of Networks. New York: Norton.

Carlsson, B. \& Stankiewicz, R. (1991). On the nature, function and composition of technological systems. Journal of Evolutionary Economics, 1(2), 93-118.

Darvas, P., Gao, S., Shen, Y. \& Bawany, B. (2017). Sharing Higher Education's Promise Beyond the Few in Sub-Saharan Africa. Washington, D.C.: World Bank Group.

FAO (Food and Agriculture Organization). (2016). State of Food and Agriculture. Rome: FAO. Geels, F.W. (2004) From sectoral systems of innovation to socio-technical systems: Insights about dynamics and change from sociology and institutional theory. Research Policy, 33(6), 897-920.

Goodman, D., DuPuis, E.M. \& Goodman, M.K. (2012). Alternative Food Networks: Knowledge, practice, and politics. London: Routledge.

Goodyear, P., \& L. Carvalho. (2013). The analysis of complex learning environments. In H. Beetham \& R. Sharpe (Eds), Rethinking Pedagogy for a Digital Age: Designing for 21st century learning. New York, NY: Routledge. pp. 49-63.

Gruenewald, D.A. \& Smith, G.A. (Eds) (2014). Place-based Education in the Global Age: Local diversity. London: Routledge.

Hakkarainen, K.P., Palonen, T., Paavola, S. \& Lehtinen, E. (2004). Communities of Networked Expertise: Professional and educational perspectives. Amsterdam: Elsevier Scientific Publishing.

Hakkarainen, K., Paavola, S., Kangas, K. \& Seitamaa-Hakkarainen, P. (2013). Toward collaborative knowledge creation. The International Handbook of Collaborative Learning. London: Routledge.

Hauck, J., Stein, C., Schiffer, E., \& Vandewalle, M. (2015). Seeing the forest and the trees: Facilitating participatory network planning in environmental governance. Global Environmental Change, 35(1), 400-410. 
IPCC (Intergovernmental Panel on Climate Change). (2014). Summary for policymakers. In Climate change 2014: mitigation of climate change. Contribution of Working Group III to the Fifth Assessment Report of the Intergovernmental Panel on Climate Change. O. Edenhofer, R. Pichs-Madruga, Y. Sokona, E. Farahani, S. Kadner, K. Seyboth, A. Adler, I. Baum, S. Brunner, P. Eickemeier, B. Kriemann, J. Savolainen, S. Schlömer, C. von Stechow, T. Zwickel, and J. C. Minx (Eds)., Cambridge, UK: Cambridge University Press.

Kabasa, J.D., Kirsten, J. \& Minde, I. (2015). Implications of changing agri-food system structure for agricultural education and training in Sub-Saharan Africa. Journal of Agribusiness in Developing and Emerging Economies, 5(2), 190-199.

Kelly, N., Bennett, J.M. \& Starasts, A. (2017). Networked learning for agricultural extension: A framework for analysis and two cases. Journal of Agricultural Education and Extension, 23(5), 399-414.

Kelly, C. \& Metelerkamp, L. (2015). Smallholder farmers and organic agriculture in South Africa. Food Lab Working Paper. South Africa: Stellenbosch University.

Kilelu C.W., Klerkx L., Leeuwis C \& Hall A. (2011). Beyond Knowledge Brokerage: An Exploratory Study of Innovation Intermediaries in an Evolving Smallholder Agricultural System in Kenya. United Nations Unveristy - Maastricht Economic and Social Research Institute on Innovation and Technology Working Paper Series \#22. Maastricht: Maastricht Graduate School of Governance.

Klerkx, L., Hall, A. \& Leeuwis, C. (2009). Strengthening agricultural innovation capacity: Are innovation brokers the answer? International Journal of Agricultural Resources, Governance and Ecology, 8, 409-438.

Lorentzen, A. (2008). Knowledge networks in local and global space. Entrepreneurship and Regional Development, 20(6), 533-545.

Losch B. (2016). Structural transformation to boost youth labour demand in sub-Saharan Africa: The role of agriculture, rural areas and territorial development. Employment and Market Policies. ILO Working Papers 994933193102676, International Labour Organization.

Lotz-Sisitka, H., Wals, A.E., Kronlid, D. \& McGarry, D. (2015). Transformative, transgressive social learning: Rethinking higher education pedagogy in times of systemic global dysfunction. Current Opinion in Environmental Sustainability, 16(1), 73-80.

Mendoza-Zuany, R.G. \& Shava, S. (2019). A South-South exchange begins to re-frame historic dialectical exclusions into situated heritage discourses of reflexive re-imagining. Southern African Journal of Environmental Education, 35(1), vii-xi.

Metelerkamp, L \& Biggs, R. (2020). Net-Map - A frontline tool for supporting place-based learning in spaces of uncertainty. CST Working Paper. Stellenbosch: Stellenbosch University. doi: 10.13140/RG.2.2.28979.99364.

Minde, I., Terblanche, F., Bashaasha, B., Madakadze, C., Snyder, J. \& Mugisha, A. (2015). Challenges for agricultural education and training (AET) institutions in preparing growing student populations for productive careers in the food system. Journal of Agribusiness in Developing and Emerging Economies, 5(2), 37-169. 
Moore, M., \& F. Westley. (2011). Surmountable chasms: Networks and social innovation for resilient systems. Ecology and Society, 16(1), 5.

O’Donoghue, R., Sandoval-Rivera, J.C.A. and Payyappallimana, U. (2019). Landscape, memory and learning to change in changing worlds: Contemplating intergenerational learning and traditional knowledge practices within social-ecological landscapes of change. Southern African Journal of Environmental Education, 35(1), 43-76.

Parr, D.M. \& van Horn, M. (2006). Development of organic and sustainable agricultural education at the University of California, Davis: A closer look at practice and theory. HortTechnology, 16(3), 426-431.

Patel, R. (2012). Stuffed and Starved: The hidden battle for the world food system. London: Portebello Books.

Pohl, C. \& Hadorn, G.H. (2007). Principles for Designing Transdisciplinary Research. Munich: Oekom.

Rauschmayer, F., Bauler, T. \& Schäpke, N. (2015). Towards a thick understanding of sustainability transitions - Linking transition management, capabilities and social practices. Ecological Economics, 109, 211-221.

Reed, M.S., Evely, A.C., Cundill, G., Fazey, I., Glass, J., Laing, A., Newig, J., Parrish, B., Prell, C. Raymond, C. \& Stringer, L.C. (2010). What is social learning? Ecology and Society, 15(4), r1.

Schiffer, E \& Waale, D. (2008). Tracing power and influence in networks: Net-Map as a tool for research and strategic network planning. IFPRI Discussion Paper 00772. Washington DC: International Food Policy Research Institute.

Schiffer, E. \& Hauck, J. (2010). Net-Map: Collecting social network data and facilitating network learning through participatory influence network mapping. Field Methods, 22(3), 231-249.

Shannon, D. \& Galle, J. (Eds.). (2017). Interdisciplinary approaches to pedagogy and place-based education: From abstract to the quotidian. Switzerland: Springer Nature.

Smith, G.A. (2002). Place-based education: Learning to be where we are. Phi Delta Kappan, 83(8), 584-594.

Sobel, D. (2004). Place-based education: Connecting classroom and community. Nature and Listening, 4, 1-7.

Spielman, D., Ekboir, J., Davis, K. \& Ochieng, C. (2008). An innovation systems perspective on strengthening agricultural education and training in sub-Saharan Africa. Agricultural Systems, 98(1), 1-9.

Stein, C. \& Barron, J. (2017). Mapping actors along value chains: Integrating visual network research and participatory statistics into value chain analysis. Colombo, Sri Lanka: WLE Research for Development (R4D) Learning Series 5. International Water Management Institute.

Tschirley, D.L., Snyder, J., Dolislager, M., Dolislager, M., Reardon, T., Haggblade, S., Goeb, J., Traub, L., Ejobi, F. \& Meyer, F. (2015). Africa's unfolding diet transformation: implications for agrifood system employment. Journal of Agribusiness in Developing and Emerging Economies, 5(2), 102-136. 
Torre, D.M., Van der Vleuten, C. \& Dolmans, D. (2016). Theoretical perspectives and applications of group learning in PBL. Medical Teacher, 38(2), 189-195.

Vallabh, P., Lotz-Sisitka, H., O’Donoghue, R. \& Schudel, I. (2016). Mapping epistemic cultures and learning potential of participants in citizen science projects. Conservation Biology, 30(3), 540-549.

Wals, A.E., Mochizuki, Y. \& Leicht, A. (2017). Critical case-studies of non-formal and community learning for sustainable development. International Review of Education, 63, 783-792.

Yeboah, F.K. \& Jayne, T.S. (2018) Africa's evolving employment trends. Journal of Development Studies, 54(5), 803-832. 
